\title{
Improving Financial Performance and Profits of Pharmaceutical Companies During a Pandemic: Study on Environmental Performance, Intellectual Capital and Social Responsibility
}

\author{
Nurul QOMARIAH ${ }^{1 *}$, Nursaid ${ }^{2}$, Eko Budi SATOTO \\ ${ }^{1}$ Master of Management Postgraduate Program, Universitas Muhammadiyah Jember, \\ E-mail: nurulqomariah@unmuhjember.ac.id \\ ${ }^{2}$ Master of Management Postgraduate Program Universitas Muhammadiyah Jember, E-mail: nursaid@unmuhjember.ac.id \\ ${ }^{3}$ Master of Management Postgraduate Program Universitas Muhammadiyah Jember, \\ E-mail: ekobudisatoto@unmuhjember.ac.id \\ ${ }^{*}$ Corresponding Author
}

Received: 25.07.2021 Accepted: 06.09.2021 Published: 02.10.2021 DOI: $\underline{\text { 10.47750/QAS/22.184.20 }}$

\begin{abstract}
The COVID-19 pandemic that has hit the world in general and Indonesia in particular has paralyzed the economies of all countries in the world, including Indonesia. The current conditions have paralyzed activities and activities, ranging from business, economics, education, and many others. Even in the COVID-19 pandemic, companies must still be able to improve their performance in order to survive. The industrial sectors that are expected to survive and thrive in the midst of the Covid-19 pandemic are food, pharmaceuticals, hospitals, and information and communication technology (ICT). The purpose of this study is to identify the role of environmental performance, intellectual capital, and corporate social responsibility in increasing profitability and financial performance of Pharmaceutical Companies listed on the Indonesia Stock Exchange for the 2017-2019 period. The research population is all pharmaceutical companies listed on the Indonesia Stock Exchange operating in Indonesia, totaling 9 companies with a measurement time of 3 years so that a sample of 27 is obtained. The data analysis method used is smart PLS analysis. The results showed that environmental performance had a positive and significant effect on profitability. Intellectual capital has no significant effect on profitability. Corporate social responsibility has a positive and significant effect on profitability. Environmental performance has no significant effect on financial performance. Intellectual capital has no significant effect on financial performance. Corporate social responsibility has a negative and significant effect on financial performance. The company's profitability has a negative and significant effect on financial performance.
\end{abstract}

Keywords: environmental performance, intellectual capital, corporate social responsibility, financial performance

\section{Introduction}

The Covid 19 pandemic that hit the world in general and Indonesia in particular has had an impact in all areas of life. The first impact that can be felt is that household consumption or purchasing power, which is the 60 percent support for Indonesia's economy, falls quite significantly. This is evidenced by data from BPS which records that household consumption fell from 5.02 percent in the first quarter of 2019 to 2.84 percent in the first quarter of this year. The second impact of a pandemic event is that it creates a prolonged uncertainty so that investment weakens and has implications for the cessation of business. Meanwhile, the third impact was that the entire world experienced a weakening economy, causing commodity prices to fall and Indonesia's exports to several countries to a halt (Https://republika.co.id/berita/qdgt5p383/tiga-dampak-besarpandemi-covid19-bagi-ekonomi-ri, 2020).
The Covid 19 pandemic has also had an impact on the growth of the industrial sector in Indonesia. Despite the pressure from the impact of the corona pandemic (Covid-19), the industrial sector still provided the largest contribution to the national gross domestic product (GDP) structure up to $19.98 \%$ in the first quarter of 2020 . The government is also determined to spur the performance of the industrial sector to continue. driving the wheels of the economy, but still adhering to health protocols. BPS data for 2020 , shows several sectors of the nonoil and gas processing industry that still recorded positive performance during the first three months of 2020, including the chemical, pharmaceutical and traditional medicine industries which grew by $5.59 \%$, then the transportation equipment industry (4.64\%) and food and beverage industry $(3.94 \%)$ (https://industri.kontan.co.id/news/sektor-industrimenyumbang-19-pdb-indonesia-di-kuartal-pertama-2020, 2020) 
Along with the Covid 19 pandemic that has hit the world in general and Indonesia in particular, many companies have been affected. The impacts on companies are manifold. There are several companies that have gone out of business and some are still able to survive even with minimal profits. Several companies that were still able to provide benefits and contributions included the chemical, pharmaceutical and traditional medicine industries which grew by $5.59 \%$, then the transportation equipment industry $(4.64 \%)$ and the food and beverage industry (3.94\%). Meanwhile, industrial sectors that are expected to survive and develop amid the Covid-19 pandemic are food, pharmaceuticals, hospitals, and information and communication technology (ICT). When the Covid 19 pandemic occurred, the food sector, the pharmaceutical sector, the hospital industry and information and communication technology were sectors that were urgent and very much needed. When people are ordered to work from home (WFH), the need for food is still fulfilled by the presence of information and communication technology by utilizing applications and Gojek and the like so that people's needs can be met. The need for medicines during the Covid 19 pandemic is also very much needed by the community to increase immunity so that they can avoid the corona virus. Thus, the contribution of the food, pharmaceutical, hospital and information and communication technology sectors to gross domestic product is a very significant increase. This research focuses on pharmaceutical sector companies listed on the Indonesia Stock Exchange for the period 2017-2019. There are around nine (9) sector companies that took part in suppressing the number of Covid 19 that hit Indonesia

The owner of a pharmaceutical company that has been registered with the Indonesian Stock Exchange, on the one hand, is required to improve its performance in order to meet the interests of shareholders. Shareholders continue to demand that the company performs well so that the share of shares for shareholders is increasing over time so that profits also increase. In addition to being required to improve financial performance, the ability to generate profits also needs attention. Company profitability is one of the company's performance measurements that can be measured in ratios to describe the company's ability to generate profits through all capabilities and resources owned by the company such as sales activities, cash, capital, number of employees, number of branches, and so on. Calculation of company profits can be seen from the Net Profit Margin / NPM which is a comparison between profit and total net income. The higher the profit, the higher the NPM, this is because the level of profitability is one way to calculate the company's efficiency by comparing the profit available to the owners of their own capital with the amount of their own capital that generates the profit. In addition to profitability, the thing that gets attention is the company's financial performance. In general, financial performance is an effort made by every company to measure and assess every success achieved in generating profits, so that the company can see the prospects, growth, and potential developments that have been achieved in the company. Financial performance appraisal is one way to fulfill obligations to investors in achieving the goals and desires that have been planned and set by the company. One measure of company performance can be seen from how the company meets short-term needs related to its financial liquidity. The liquidity ratio shows the company's ability to meet short-term financial obligations (Gumanti, 2011). Such as paying salaries, maturing debts, operating costs, and others. There are many factors in an effort to increase the company's profits and financial performance. Several factors that are allegedly able to increase profitability and financial performance include: environmental performance. intellectual capital, corporate social responsibility.
This study has research questions, including: first, can environmental performance increase the profitability of pharmaceutical companies? second, can intellectual capital increase the profitability of pharmaceutical companies? Third, can corporate social responsibility increase the profitability of pharmaceutical companies? Fourth, can environmental performance improve the financial performance of pharmaceutical companies? Fifth, can intellectual capital improve the financial performance of pharmaceutical companies? Sixth, can corporate social responsibility improve the financial performance of pharmaceutical companies? And lastly, can the company's profitability improve the financial performance of pharmaceutical companies?. While the objectives of this study are: First, to determine the impact of environmental performance on the profitability of pharmaceutical companies. Second, to determine the impact of intellectual capital on the profitability of pharmaceutical companies. Third, to determine the impact of corporate social responsibility on the profitability of pharmaceutical companies. Fourth, to determine the impact of environmental performance on the financial performance of pharmaceutical companies. Fifth, to determine the impact of intellectual capital on the financial performance of pharmaceutical companies. Sixth, to determine the impact of corporate responsibility on the financial performance of pharmaceutical companies, Finally, to determine the impact of company profitability on the financial performance of pharmaceutical companies.

\section{Literature Review and Hypotheses}

\section{The Relationship Between Environmental Performance With Company Profitability}

The concept of environmental performance usually refers to the amount of environmental damage caused by business activities carried out by the company (Putri et al., 2019). Environmental damage resulting from less company operations will improve environmental performance. Conversely, the greater the impact of environmental damage, the worse the company's performance. The rating program can be used to assess capabilities in environmental management or is called PROPER. Profitability is the company's ability to earn a profit in terms of sales that have been made. Companies that have high profits mean good performance and vice versa. In increasing company profits, companies can effectively and efficiently manage their resources. Research (Putri et al., 2019),(Nawangsari \& Nugroho, 2019), (Asjuwita \& Agustin, 2020), (Mardiana \& Wuryani, 2019) states that environmental performance can increase company profitability. Based on the theory and empirical studies that have been carried out by several researchers, the hypothesis in this study is $\mathrm{H} 4$ : environmental performance has an influence on company profitability.

\section{The Relationship Between Intellectual Capital and Company Profitability}

Intellectual capital can be interpreted as intellectual material that has been formalized, captured, and leveraged to create wealth, by producing an asset of high value for the company's sustainability (Ihyaul, 2009). The increasing phenomenon of IC causes the measurement method of IC to become an important topic, considering the potential benefits that can be obtained by the company either directly or indirectly on the management of the company's IC assets. IC asset management which will have an impact on efforts to increase company profits. The role of intellectual capital for companies is increasingly strategic because many companies have realized the role of intellectual 
capital by making intellectual capital the key in increasing profits for the company (Marfuah \& Ulfa, 2014). Several studies linking IC with company profitability include : (Cahyani et al., 2015), (Qomariah et al., 2019), (Hermanus et al., 2013), (Marfuah \& Ulfa, 2014), (Halim et al., 2016) stating that intellectual capital can increase company profitability. Based on the theory and empirical studies that have been carried out by several researchers, the hypothesis in this study is $\mathrm{H} 5$ : intellectual capital has an influence on company profitability.

\section{The Relationship Between Corporate Social Responsibility and Corporate Profitability}

Corporate social responsibility can be interpreted as the commitment of the company or the business world to contribute to sustainable economic development by paying attention to corporate social responsibility and focusing on the balance between attention to economic, social and environmental aspects (Untung, 2009). Corporate social responsibility has an impact on increasing the company's economic performance, such as: increasing sales, market legitimacy, increasing investors in the capital market, increasing value for the welfare of owners and the like (Hadi, 2011). The community will give an assessment of the company that pays attention to the surrounding environment from economic, social and environmental aspects. Corporate Social Responsibility (CSR) can be used as a new marketing tool for companies if it is carried out continuously with the hope that company profits can increase. Research (A. S. Putra, 2016), (Rahayu et al., 2014)states that corporate social responsibility can increase the company's profit. Based on the theory and empirical studies that have been carried out by several previous researchers, the hypothesis in this study is $\mathrm{H} 6$ : corporate social responsibility has an influence on company profitability.

\section{The Relationship between Environmental Performance and Financial Performance}

Several studies on the disclosure of environmental and social information use legitimacy theory as a basis in explaining the practice of disclosing environmental information (Patten, 1992). Environmental performance is a measurable result of the environmental management system, which is related to the control of environmental aspects. Environmental performance assessment is based on environmental policy. Environmental targets and environmental targets (ISO 14001). Companies that pay attention to the surrounding environment are related to the company's environment and the impact caused by the existence of the company will provide a positive value for the community towards the company's existence in the eyes of the community. A positive assessment from the community will have a positive impact on the company's existence so that it can increase the company's profits and financial performance. Disclosure of environmental performance will have an impact on financial performance. Disclosure of environmental performance will have an impact on financial performance stated by several studies such as: (Nakao et al., 2007), (Testa et al., 2011), (Aniela, 2012), (Fitriani, 2013), (Haholongan, 2016), (Y. P. Putra, 2018), (Tahu, 2019), (Hardiyansah \& Agustini, 2020). (Manrique \& Martí-Ballester, 2017) also conducts research related to environmental performance which is linked to the company's financial performance. (Elsayed \& Paton, 2005) states that environmental performance has a neutral impact on firm performance. (Al-Tuwaijri et al., 2004) in his research revealed that "good" environmental performance is significantly associated with "good" economic performance, and also with more extensive quantifiable environmental disclosures of specific pollution measures and occurrences. Similar research was also expressed by (Meiyana \& Aisyah, 2019), (Nurhudha \&
Suwarti, 2013), (Ong et al., 2019). Based on the results of previous research, the following hypotheses were formulated. $\mathrm{H} 1$ : Environmental performance has an influence on the company's financial performance.

\section{The Relationship Between Intellectual Capital and Financial Performance}

Intellectual capital is one of the important strategic assets in economic-based knowledge (S. D. Lestari et al., 2017). High human capital will be able to encourage increased profits and financial performance of the company. Human capital is a combination of knowledge, skills, innovation and a person's ability to carry out their duties so that they can create value. The most valuable asset in a company is Human Resources (HR), especially intellectual capital (Nurhayati, 2017). Knowledgebased management patterns encourage companies to be able to manage intellectual capital effectively because intellectual capital is part of the intangible assets owned by the company. The company's intangible assets such as intellectual capital have the potential to increase the added value of the company, therefore it needs good maintenance (Khasanah, 2016). Intellectual capital is an asset that is not real by nature, which is currently stated as the company's main asset in the form of a strategy that can increase the company's ability to compete and increase financial performance to a superior level $(\mathrm{H}$. S. Lestari, 2017). Disclosure of information about intellectual capital (IC) in the annual report is one of the disclosures that is voluntary (Ihyaul, 2009).

(Kurniawan, 2013), (Haryanto \& Henny, 2013), (Iskandar et al., 2019), (Nursaid et al., 2020) states that companies that pay attention to the capital they have can improve the company's financial performance, because this capital is very important in a company. Similar statements were also expressed by several researchers regarding the relationship between intellectual capital and financial performance as expressed by: (Ongkorahardjo et al., 2008), (Santoso, 2011), (W \& Firmansyah, 2012), (Gozali \& Hatane, 2014), (Gozali \& Hatane, 2014), (Sirojudin, Gatot Ahmad; Nazaruddin, 2014),(Agustina et al., 2015), (Habibah \& Riharjo, 2016), (Dženopoljac et al., 2016), (H. S. Lestari, 2017), (Cahyono \& Qomariah, 2017), (Sumani \& Suryaningsih, 2020). Several other studies that also link intellectual capital issues with company financial performance and state that intellectual capital can improve the company's financial performance if it is managed properly, including: (Janosevic \& Dzenopoljac, 2011), (Jordão \& de Almeida, 2017), (Suseno et al., 2019), (Yusuf et al., 2020), (Gama et al., 2020), (Silviani \& Noekent, 2020), (Azzahra, 2020), (Yurianda \& Masdupi, 2020), (Hidayah et al., 2020), (R. Muhammad et al., 2021). Based on theory and empirical studies that have been conducted by several researchers, the second hypothesis in this study is H2: intellectual capital has an influence on the company's financial performance.

\section{The Relationship Between Corporate Social Responsibility and Financial Performance}

The social impact of the activities of a company is an important issue to be studied lately. This is because social impacts are closely related to company risks that arise from the relationship between the company and its stakeholders. Bad social impacts will increase the company's risk, disrupt relationships with stakeholders and ultimately affect the company's reputation (Darmawati, 2015). Companies are required to have social concern for the communities in which the company operates. This company's concern will have a positive value and in the end it can increase the company's profits and financial performance. Corporate social responsibility includes several aspects within the company, including relationships with 
employees, diversity, human rights activities, healthy products and also corporate governance and compensation policies (Pramukti \& Buana, 2019).CSR is a corporate responsibility based on three basic principles known as the triple bottom line which consists of profit, people and planet (Pramukti \& Buana, 2019). Corporate Social Responsibility can be used as a new marketing tool for companies if it is implemented sustainably. Corporate social responsibility is a company effort to pay attention to the environment in which the company does business. The company's business operations are committed not only to increasing corporate profits financially, but also to the development of a socio-economic area in a holistic, institutionalized and sustainable manner (Pratiwi \& Setyoningsih, 2010). Corporate social responsibility is a mechanism for a company to voluntarily integrate attention to the social environment into its operations and interactions with stakeholders, which goes beyond social responsibility in the legal field (Nurhuda \& Suwarti, 2011). Corporate social responsibility is a company effort to provide part of the profits it manages for corporate social activities (Qomariah, 2015).

Research that links corporate social responsibility with financial performance results that corporate social responsibility carried out by the company can make company performance increase, among others, carried out by:, (Tang et al., 2012), (Hamdani, 2014), (Darmawati, 2015), (Suciwati et al., 2016), (Yoon \& Chung, 2018), (Cho et al., 2019), (Hafidzi \& Qomariah, 2020). (Angelia \& Suryaningsih, 2015) also argued that CSR disclosure had a significant effect on ROE, but had no effect on ROA. Companies that have a social responsibility to the community and the surrounding environment will be recognized by the community, which later on the products of the company will also be known by the community (Sari \& Sinambela, 2008), (Angelia \& Suryaningsih, 2015), (Darmawati, 2015), (Yulianingtyas, 2016), , (Suciwati et al., 2016). Companies are required to pay attention to the surrounding environment and society with concern in the form of corporate social responsibility. This corporate responsibility can take the form of community welfare through good business practices and contributing a portion of the company's resources (Bidhari et al., 2013), (Hamdani, 2014), , (Hamdani, 2014), (Hafidzi \& Qomariah, 2020). Based on theory and empirical studies that have been conducted by several researchers, the second hypothesis in this study is H3: Corporate social responsibility has an influence on the company's financial performance.

\section{The Relationship Between Company Profitability and Company Financial Performance}

Profitability can be interpreted as a measure used to assess the extent to which the company is able to generate profits at an acceptable level so that the company is able to survive. The company as a form of organization generally has a goal to achieve maximum profit or profit, both short-term and long-term goals (Gumanti, 2011). (Fahmi, 2014) said that performance is a description of the achievements achieved by the company in its operational activities, both in terms of financial aspects, marketing aspects, aspects of raising funds and distributing funds, technological aspects, and aspects of human resources. There are many studies that link the company's profitability with the company's financial performance. (Halim et al., 2016), (IMGD Putra \& Dana, 2016), (Surmadewi \& Saputra, 2019), (Sudaryo \& Pratiwi, 2016), (Gultom \& Wijaya, 2013), (Pasaribu \& Tobing, 2017) conducted research on the relationship between the company's profitability with the company's financial performance, the result is that the company's profitability can improve the company's financial performance. Based on the theory and empirical studies that have been carried out by several previous researchers, the hypothesis in this study is $\mathrm{H7}$ : The company's profitability has an influence on the company's financial performance.

\section{Data and Methodology}

This research is a causal research, where in this study will be analyzed the effect of environmental performance variables, intellectual capital, corporate social responsibility on profitability and corporate financial performance of pharmaceutical companies listed on the Indonesia Stock Exchange for the period 2017 to 2019. The population of this study is a Pharmaceutical Company listed on the Indonesia Stock Exchange for the period 2017-2019 with purposive sampling technique. There are currently 9 pharmaceutical companies listed on the Indonesia Stock Exchange, including: PT Merck Indonesia Tbk, PT Kalbe Farma Tbk, PT Tempo Scan Pacific Tbk, PT Darya Varia Laboratoria Tbk, PT Indofarma (Persero) Tbk, PT Kimia Farma ( the Company) Tbk, PT Pyridam Farma Tbk, PT Industri Jamu and Pharmaceuticals Sido Muncul Tbk, PT Pharos Tbk. There are 9 pharmaceutical companies listed on the Indonesia Stock Exchange operating in Indonesia with a measurement period of 3 years so that a sample of 27 is obtained. The independent variables in this study include: environmental performance, intellectual capital, corporate social responsibility. While the intervening variable is the company's profitability. The dependent variable is the company's financial performance variable. Environmental performance indicators are proxied by PROPER. Intellectual capital indicator is proxied by VAIC. Indicators of corporate social responsibility are proxied by the CSR Index. Company profitability indicator is proxied by Net Profit Margin (NPM). Meanwhile, financial performance is prorated by the current ratio. Data analysis in this study used SEM-PLS with WarpPLS 5.0. This study uses the SEM technique, so that the evaluation is carried out on two models, namely the outer model and the inner model.

\section{Results and Discussion}

\section{Descriptive Statistics Results}

The results of the descriptive statistics of the research variables consist of environmental performance, intellectual capital, and corporate social responsibility and financial performance. The results of descriptive statistical analysis for research variables can be presented in Table 1.

\section{Inner Weight Analysis Results}

The results of the inner weight analysis are used to test the research hypotheses between the variables studied. The significance of the estimated parameters provides very useful information about the relationship between the research variables. The results of the inner weight analysis which is the estimated output for testing the structural model are presented in Table 2. 


\section{GENERAL MANAGEMENT}

\begin{tabular}{|l|l|l|l|l|l|}
\hline & $\mathrm{N}$ & Minimum & Maximum & Mean & Std. Deviation \\
\hline $\begin{array}{l}\text { Environmental } \\
\text { Performance }\end{array}$ & 27 & .00 & 4.00 & 2.0000 & 1.86052 \\
\hline Intelectual Capital & 27 & .40 & 4.86 & 1.5250 & 1.23587 \\
\hline $\begin{array}{l}\text { Corporate Social } \\
\text { Responsibility }\end{array}$ & 27 & .28 & .46 & .3520 & .05831 \\
\hline Profitability & 27 & -2.84 & 101.37 & 12.7926 & 19.18431 \\
\hline Financial performance & 27 & .99 & 465.77 & 154.3841 & 169.33708 \\
\hline Valid N (listwise) & 27 & & & & \\
\hline
\end{tabular}

\begin{tabular}{|l|l|l|l|l|l|}
\hline Variable & $\begin{array}{l}\text { Original Sample } \\
\text { Estimate }\end{array}$ & $\begin{array}{l}\text { Mean of } \\
\text { Sub- } \\
\text { samples }\end{array}$ & $\begin{array}{l}\text { Standard } \\
\text { Deviation }\end{array}$ & T-Statistic & Annotation \\
\hline EP $->$ PROF & 0,369 & 0,392 & 0,062 & 5,923 & Significant \\
\hline IC $>$ PROF & $-0,057$ & $-0,054$ & 0,062 & 0,914 & Not Significant \\
\hline CSR $->$ PROF & 0,178 & 0,179 & 0,073 & 2,466 & Significant \\
\hline EP $->$ FP & $-0,080$ & 0,084 & 0,109 & 0,736 & Not Significant \\
\hline IC $->$ FP & 0,111 & 0,121 & 0,102 & 1,093 & Not Significant \\
\hline CSR $->$ FP & $-0,328$ & $-0,317$ & 0,073 & 3,657 & Significant \\
\hline PROF $>$ FP & $-0,228$ & $-0,237$ & 0,041 & 5,605 & Significant \\
\hline
\end{tabular}

The results of the statistical analysis in Table 2. are the results of testing the hypothesis of each path formed in the model to determine the effect of exogenous latent variables on endogenous latent variables.

The path parameter coefficient obtained from the relationship between environmental performance and profitability is 0.369 with a T-statistic value of $5.923>2.052$ at a significant level of $=0.05(5 \%)$. Based on these results the data stated that there is a significant effect of environmental performance on profitability. So that the hypothesis that environmental performance affects profitability is proven true or $\mathrm{H} 1$ is accepted.

The path parameter coefficient obtained from the relationship between intellectual capital and profitability is 0.057 with a T-statistic value of $0.914<2.052$ at a significant level of $=0.05(5 \%)$. Based on these results, it is stated that there is no significant influence of intellectual capital on profitability. So that the hypothesis which states that intellectual capital affects profitability is not proven true or $\mathrm{H} 2$ is rejected.

The path parameter coefficient obtained from the relationship between corporate social responsibility and profitability is 0.178 with a T-statistic value of $2.466>2.052$ at a significant level of $=0.05(5 \%)$. Based on these results, it is stated that there is a significant effect of corporate social responsibility on profitability. So that the hypothesis which states that corporate social responsibility affects profitability is proven true or $\mathrm{H} 3$ is accepted.

The path parameter coefficient obtained from the relationship between environmental performance and financial performance is -0.080 with a t-statistic value of $0.736<2.052$ at a significant level of $=0.05(5 \%)$. Based on these results, it is stated that there is no significant effect of environmental performance on financial performance. So that the hypothesis that environmental performance affects financial performance is not proven true or $\mathrm{H} 4$ is rejected.

The path parameter coefficient obtained from the relationship between intellectual capital and financial performance is 0.111 with a t-statistic value of $1.093<2.052$ at a significant level of $=0.05(5 \%)$. Based on these results, it is stated that there is no significant influence of intellectual capital on financial performance. So that the hypothesis which states that intellectual capital affects financial performance is not proven true or $\mathrm{H} 5$ is rejected.

The path parameter coefficient obtained from the relationship between corporate social responsibility and financial performance is -0.328 with a T-statistic value of 3.657 $>2.052$ at a significant level of $=0.05(5 \%)$. Based on these results, it is stated that there is a significant influence of corporate social responsibility on financial performance. So that the hypothesis which states that corporate social responsibility affects financial performance is proven true or $\mathrm{H} 6$ is accepted.

The path parameter coefficient obtained from the relationship between profitability and financial performance is 0.228 with a T-statistic value of $5.605>2.052$ at a significant level of $=0.05(5 \%)$. Based on these results, it is stated that there is a significant effect of profitability on financial performance. So that the hypothesis which states that profitability affects financial performance is proven true or $\mathrm{H} 7$ is accepted.

\section{Path Analysis Calculation Results}

This section describes the calculation of the effect of environmental performance, intellectual capital, and corporate social responsibility as independent variables $(X)$ affecting profitability $(Z)$ and financial performance $(Y)$. The results of calculating the path coefficient hypothesis in the study are presented in Figure 1. 


\section{GENERAL MANAGEMENT}

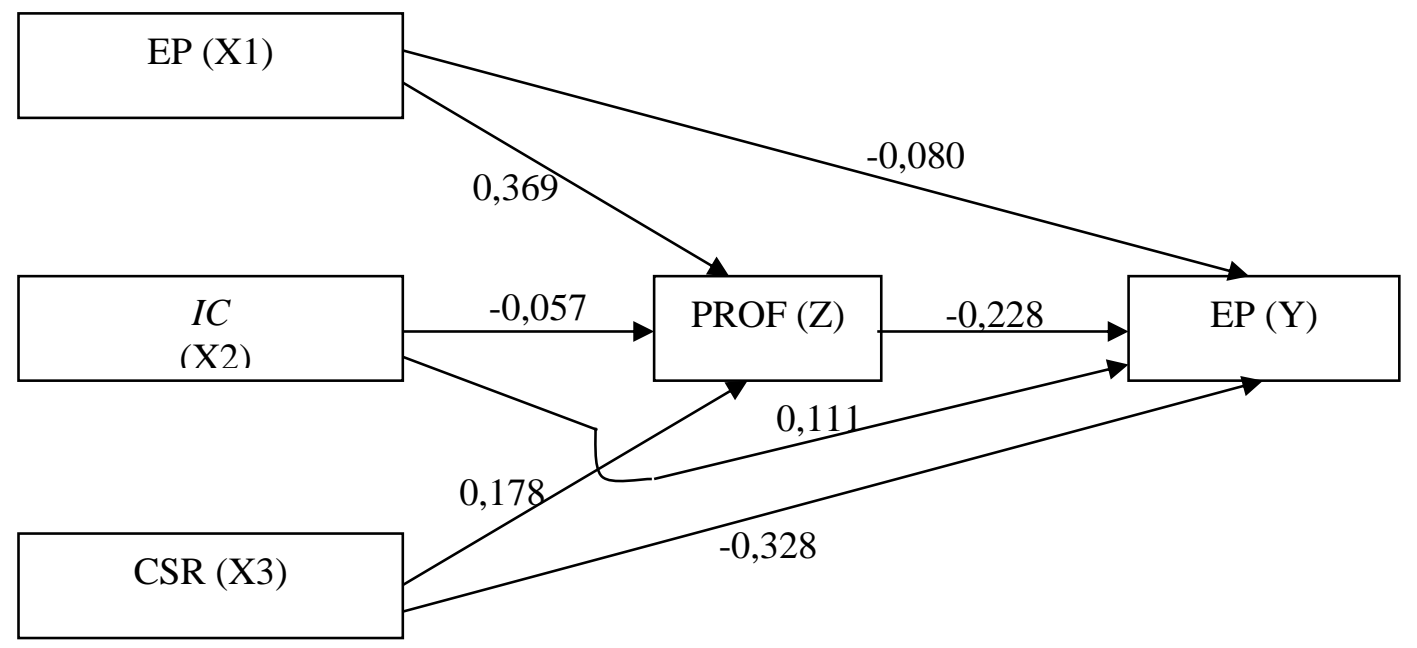

\begin{tabular}{|l|l|l|l|}
\hline & Direct Effect & Indirect Effect & Total Effect \\
\hline PZX1 & 0,369 & & 0,369 \\
\hline PZX2 & $-0,057$ & & $-0,057$ \\
\hline PZX3 & 0,178 & & 0,178 \\
\hline $\begin{array}{l}\text { PYX1 } \\
\text { Indirect Effect (via Z) }\end{array}$ & $-0,080$ & 0,084 & 0,164 \\
\hline $\begin{array}{l}\text { PYX2 } \\
\text { Indirect Effect (via Z) }\end{array}$ & 0,111 & 0,013 & 0,124 \\
\hline $\begin{array}{l}\text { PYX3 } \\
\text { Indirect Effect (via Z) }\end{array}$ & $-0,328$ & & 0,369 \\
\hline PYZ & $-0,228$ & 0,041 & 0,228 \\
\hline
\end{tabular}

Based on the calculation results in Figure 1. it can be seen the magnitude of the direct influence of each independent variable $(\mathrm{X})$ both on the dependent variable $(\mathrm{Y})$ and the intervening variable $(Z)$. The indirect effect of each independent variable $(X)$ on the dependent variable $(Y)$ through the intervening variable $(Z)$ can be calculated as follows: The effect of environmental performance on financial performance through profitability $=0.369 \times 0.228=0.084$. The influence of intellectual capital on financial performance through profitability $=0.057 x$ $0.228=0.013$. The effect of corporate social responsibility on financial performance through profitability $=0.178 \times 0.228=$ 0.041 . The results of the calculation of the path analysis of direct and indirect effects are presented in Table 3.

Based on the statistical calculations in Table 3., it is known that the direct effect test for the path coefficient between environmental performance and profitability $(Z)$ is $36.9 \%$ positive. Testing the direct effect for the path coefficient between intellectual capital on profitability $(Z)$ is negative at $5.7 \%$. The direct effect test for the path coefficient between corporate social responsibility and profitability $(Z)$ is positive at $17.8 \%$.

\section{Discussion}

\section{The Effect of Environmental Performance on Company Profitability}

The results of statistical analysis state that environmental performance has an effect on company profitability. Thus the first hypothesis which says that environmental performance
The direct effect test for the path coefficient between environmental performance and financial performance $(Y)$ is negative at $8.0 \%$. Testing the direct effect for the path coefficient between intellectual capital on financial performance $(Y)$ is positive at $11.1 \%$. The direct effect test for the path coefficient between corporate social responsibility and financial performance $(Y)$ is negative at $32.8 \%$. Testing the direct effect for the path coefficient between profitability and financial performance $(\mathrm{Y})$ is negative at $22.8 \%$.

The indirect effect test for the path coefficient between environmental performance and financial performance $(Y)$ through profitability $(Z)$ is negative at $8.4 \%$. Testing the indirect effect for the path coefficient between intellectual capital on financial performance $(Y)$ through profitability $(Z)$ is negative at $1.3 \%$. Testing the indirect effect for the path coefficient between intellectual capital on financial performance $(Y)$ through profitability $(Z)$ is negative at $4.1 \%$. Based on these results, it can be stated that the indirect effect of environmental performance on financial performance $(Y)$ through profitability $(Z)$ is the largest indirect effect.

affects the company's profitability is accepted ( $\mathrm{H} 1$ is accepted). The test results show that the environmental performance variable has a positive and significant effect on profitability. The positive effect indicates that the better the environmental performance as proxied by the PROPER rating, the better the company's profitability. This shows that the awards obtained from activities held by the Ministry of the Environment can increase the company's profitability. Through environmental activities and disclosure of these activities in the annual report, users of financial statements (investors, management, 
creditors) will get information that can assist users of that information in making decisions for company policies or programs related to environmental conservation in the future. will come. These programs will be supported by the community and consumers, which in the end the community and consumers will have high trust in the company. This trust will encourage consumers to become loyal consumers for the company, where this loyalty will increase sales of products issued by the company. Companies in implementing environmental performance and environmental disclosure will require no small amount of funds. So the company needs a high level of profitability in order to provide benefits for investors and continue to carry out its social responsibility to the environment and society. Disclosure made by companies can generate many advantages. The company fulfills social needs and higher selfdisclosure, increases public trust while increasing the company's image in the eyes of the public who will buy the company's products or invest in the company's operations through investment. Environmental disclosure has a positive effect on company profitability, which makes environmental disclosure a thing that can be applied by companies to increase the company's profitability.

Research (Putri et al., 2019),(Nawangsari \& Nugroho, 2019), (Asjuwita \& Agustin, 2020), (Mardiana \& Wuryani, 2019) states that environmental performance can increase company profitability. Based on the theory and empirical studies that have been carried out by several researchers, the hypothesis in this study is $\mathrm{H} 4$ : environmental performance has an influence on company profitability.. Research that is not in line with this research is research conducted by: (Sulistiawati \& Dirgantari, 2017), (Asjuwita \& Agustin, 2020) whose results state that environmental performance has no effect on company profitability.

\section{The Influence of Intellectual Capital on Company Profitability}

The results of statistical calculations show that intellectual capital has no effect on the company's profitability. Thus the second hypothesis which states that intellectual capital affects the company's profitability is rejected ( $\mathrm{H} 2$ is rejected). The results of this test indicate that the intellectual capital variable has no significant effect on profitability. The insignificant finding indicates that intellectual capital as proxied by VAIC is not a factor that determines the company's profitability. The insignificant effect indicates that the company is not optimal in the paradigm of labor management patterns. The company has not been able to utilize intellectual capital into a competitive advantage. The company still applies a labor-based business management pattern compared to knowledge-based business management, so that the main characteristics of the company are not yet a science-based company. Intellectual capital plays an important role in increasing the company's ability to create competitive advantage (Ihyaul, 2009). Therefore, another benefit obtained by companies by reporting intellectual capital, in addition to communicating their advantages, companies can also attract value-added resources. However, the exact measurement of the company's intellectual capital has not been determined. Several studies linking IC with company profitability include: (Cahyani et al., 2015), (Qomariah et al., 2019), (Hermanus et al., 2013), (Marfuah \& Ulfa, 2014), (Halim et al., 2016) stating that intellectual capital can increase company profitability. Research that is not in line with this research are: (Hermanus et al., 2013), (Juanda et al., 2016)which states that intellectual capital has no effect on company profitability.

\section{The Effect of Corporate Social Responsibility on Corporate Profitability}

The test results accept the third hypothesis $(\mathrm{H} 3)$ which states corporate social responsibility on profitability. The test results show that the variable of corporate social responsibility has a positive and significant effect on profitability. The positive effect indicates that the better the corporate social responsibility as proxied by the CSR index, the better the company's profitability. This corporate social responsibility arises from a conflict of interest between the company and the surrounding community due to the negative impacts arising from the existence of a company in a certain environment. After realizing the usefulness of disclosing social responsibility information, in deciding to disclose social information, the company will consider the costs and benefits that will be obtained. If the benefits obtained are greater than the costs of disclosing corporate social information, the company will voluntarily disclose the information. However, this is not the case if the costs incurred by the company to disclose social responsibility or CSR are greater than the benefits obtained.

Corporate social performance is quite important for the company's image, especially for the long term company that can make a significant contribution to the sustainable development of the company. If the company implements CSR, then the company has a motive to increase profits. The second motive, companies implement CSR, to reduce threats or pressure from the government or NGO activists. The third motive is because of moral awareness, selfless to get financial benefits, companies consciously respond to the need for the importance of attention to the environment. The three motives above, it can be seen that the movements carried out by the company are actually strategic or ethical in nature. Thus, corporate social performance can be a measure of the company's image or reputation. The image or reputation of the company itself is one of the most valuable assets. From here it can be used as a starting point why CSR is one of the key components that are important for the development of a company's reputation. The better the company's reputation, the better the company's ability to run its business and ultimately will increase the company's profitability. Research that supports this research is research: (A. S. Putra, 2016), (Rahayu et al., 2014), (Almar et al., 2012), (Septiana \& DP, 2012), (F. A. Putri et al., 2014), (Fadila \& Utiyati, 2016), (Rosdwianti et al., 2016) states that corporate social responsibility can increase the company's profit. Research that does not support this research is research conducted by: (Qomariah et al., 2019), (Iskandar, 2016), (Artista et al., 2015) which states that corporate social responsibility has no impact on company profitability.

\section{The Effect of Environmental Performance on Financial Performance}

The test results reject the fourth hypothesis $(\mathrm{H} 4)$ which states environmental performance on financial performance. The test results show that the environmental performance variable does not have a significant effect on financial performance. The insignificant effect indicates that environmental performance as proxied by PROPER rating is not a factor that determines the company's financial performance. The insignificant finding is due to the fact that there are still pharmaceutical companies in Indonesia that do not follow the PROPER rating implemented by the Indonesian Ministry of Environment. This indicates a lack of company awareness regarding environmental responsibility.

The company's environmental responsibility can be assessed from the company's environmental performance. Stakeholders can assess the extent of the company's 
environmental performance by looking at the color ratings obtained by the company through the Company Performance Rating Program (PROPER) organized by the Ministry of Environment $(\mathrm{KLH})$. The better the environmental activities carried out by the company will lead to increased trust in the eyes of stakeholders so that it has an impact on financial performance. A natural resource-based view of managing stakeholder expectations through improving environmental performance, companies can develop valuable, scarce, inimitable and non-substitutable resources. The total benefits from environmental performance include increased revenue through increased operational efficiency and environmental reputation, and a reduction in environmental risk by preventing environmental disasters that could have a negative impact on company performance. Environmental improvements can improve a company's reputation. The environmental reputation of a company is related to the reputation of other companies in the same industry. In other words, companies in the same industry have the same reputation. By being environmentally friendly, companies can collectively improve the general reputation of the industry. Improved environmental performance can reduce the company's operational risk from environmental pollution and prevent boycotts from stakeholders. Furthermore, proactive environmental practices can reduce environmental regulatory compliance costs and increase employee morale and productivity.

The results of this study are not in line with research conducted by several researchers, including: (Y. P. Putra, 2018), (Hardiyansah \& Agustini, 2020). (Haholongan, 2016), (Fitriani, 2013), (Nakao et al., 2007), (Aniela, 2012), (Testa et al., 2011), (Tahu, 2019), (Manrique \& Martí-Ballester, 2017), (Elsayed \& Paton, 2005), (Meiyana \& Aisyah, 2019), (Nurhudha \& Suwarti, 2013), (Ong et al., 2019) which states that environmental performance can improve financial performance. The results of this study are in line with the research (Astuti et al., 2014), (Deswanto \& Siregar, 2018), (Setyaningsih \& Asyik, 2016), (N. Muhammad et al., 2015) which states that environmental performance has an influence on financial performance.

\section{The Effect of Intellectual Capital on Financial Performance}

The test results reject the fifth hypothesis (H5) which states that intellectual capital has an effect on financial performance. The test results show that the variable intellectual capital does not have a significant effect on financial performance. The insignificant finding indicates that the intellectual capital proxied by VAIC is not a factor that determines the company's financial performance. The insignificant finding on the company's financial performance means that it proves that the company has not managed and developed its resources and is still focused on short-term interests, namely company returns.

In accordance with the Resource Based Theory, a company that is able to manage intellectual capital well will have a competitive advantage and is believed to be able to create added value that will affect the company's financial performance. Intellectual capital is recognized as a company asset because it is able to generate competitive advantages and superior financial performance. The better the company is in managing the three components of intellectual capital, the better the company is in managing its assets. If a company can produce goods according to consumer needs, provide satisfying services and maintain good relationships with consumers, then this is a competitive advantage the company has. Intellectual capital has the benefit of improving the company's financial performance so as to create a competitive advantage. The company's financial performance is a result that utilizes resources. The use of cash and assets in financing the company's operations is a parameter in measuring financial performance. Therefore, the company's ability to manage cash and assets and generate profits is needed by a company for the survival of the company. Profits will be obtained if the company continues to carry out its operational activities. The company's operational activities will be achieved if it has resources who are knowledgeable and competent in their fields. Profits will provide a positive signal for the company's future prospects regarding the company's financial performance so that with the continued increase in profit growth, it will provide a positive signal for the company's financial performance. Based on these arguments, it can be seen that the important role of intellectual capital in achieving optimal corporate financial performance. Therefore it is necessary to pay attention to the practice of managing intangible assets has increased dramatically. One approach used to measure intangible assets is intellectual capital, which has become the focus of attention in various fields, including management, information technology, sociology and accounting. The company must be able to quickly change its business strategy from a labor-based business to a knowledgebased business, so that the main characteristics of the company become a science-based company and make intellectual capital an element of the company's competitive advantage.

The results of this study are in line with research conducted by several researchers such as (Cahyaningrum \& Atahau, 2020), which stated that intellectual capital does not affect financial performance. This research is not in line with several studies that have also been conducted, including: (Janosevic \& Dzenopoljac, 2011), (Suseno et al., 2019), (Silviani \& Noekent, 2020), (Hidayah et al., 2020), (Yusuf et al., 2020), (Gama et al., 2020), (Azzahra, 2020), (Jordão \& de Almeida, 2017), (Yurianda \& Masdupi, 2020), (R. Muhammad et al., 2021), (Khasanah, 2016), which states that intellectual capital can improve the company's financial performance.

\section{The Effect of Corporate Social Responsibility on Financial Performance}

The sixth hypothesis states that social responsibility has an influence on the company's financial performance. After statistical testing, the results state that corporate social responsibility has an effect on financial performance. The test results show that the corporate social responsibility variable has a positive and significant effect on financial performance. The positive effect shows that the better corporate social responsibility, which is proxied by the CSR Index, will be able to increase the company's financial performance as measured by $\mathrm{CR}$. This can be explained that the increase in CSR by the company will certainly provide benefits to the community. People who benefit from the company's activities in the form of corporate responsibility will make the company known to the public which will have an impact on increasing sales of products from the company. The results of this study indicate that companies that have financial performance in terms of liquidity tend to perform better CSR disclosures, this is inseparable from the support of good financial capacity and is related to the company's reputation that must be maintained.

Companies that have a solid financial performance have more resources to invest in the domain of social performance. Signal theory states that companies provide signals to outsiders with the aim of increasing firm value. In addition to the required financial information, the company also makes voluntary disclosures. Stakeholder theory holds that companies must carry out social disclosure as a responsibility to stakeholders. This study uses CSR as an independent variable with the idea that the market will provide a positive appreciation which can have an impact on improving the company's performance and ability to earn a profit. 
Research on the relationship between social responsibility and financial performance has been carried out by several researchers, including: (Gantino, 2016), (Sudaryanti \& Riana, 2017), (Yulianingtyas, 2016), (Sari \& Sinambela, 2008), (Hamdani, 2014), (Hafidzi \& Qomariah, 2020), (Suciwati et al., 2016), (Darmawati, 2015), (Tang et al., 2012), (Angelia \& Suryaningsih, 2015), (Cho et al., 2019), which states that corporate social responsibility can improve the company's financial performance. This research is not in line with several studies, including:(Kusuma \& Syafruddin, 2014), (Parengkuan, 2017), (Yoon \& Chung, 2018), (Qomariah, 2015) which states that social responsibility has no impact on the company's financial performance.

\section{The Influence of Company Profitability on Financial Performance}

The results of statistical testing accept the seventh hypothesis (H7) which states profitability on financial performance. The test results show that the company's profitability variable has a negative and significant effect on financial performance. The negative effect indicates that the better the company's profitability as proxied by NPM, the lower the company's financial performance as measured by CR. The decrease in CR was due to the expenditure of operational costs for activities carried out by the company. The company's cash which is an important element of CR in corporate financing will be used as financing for the company's operations, which in the end is intended to increase profits as an element of NPM. Cash is reduced, then the $C R$ will be smaller, on the other hand the impact of this increasing company profits, the NPM will increase.

In achieving the company's goals, the company's performance is needed which is a parameter or benchmark for the company's success. The company's performance can be measured by various methods of financial analysis, but one of the company's performance measurement uses the liquidity ratio. Liquidity also has an important role in the success or smooth running of the company. (Gumanti, 2011) suggests that liquidity plays an important role in the successful functioning of a company's business. Current ratio is a ratio used to measure the company's ability to meet its short-term obligations. Liquidity management is also very necessary in all small, medium, and large businesses to be able to pay short-term debt without any difficulty in paying because by collecting money from customers on time.

Profitability ratios are financial analysis tools used to determine company boundaries (Gitman \& Zutter, 2015). Therefore, financial managers carry out a good corporate management strategy so that the company gets profitability to improve the progress and survival of the company. If the company does not care about profits, the company cannot survive longer, whereas if the company does not care about liquidity, it will experience incapacity or bankruptcy. Research that is in line with this research is research conducted by: Halim et al., 2016), (IMGD Putra \& Dana, 2016), (Surmadewi \& Saputra, 2019), (Sudaryo \& Pratiwi, 2016), (Gultom \& Wijaya, 2013), (Pasaribu \& Tobing, 2017) stated that the company's profitability can improve the company's financial performance. While the research that does not support this research is research: (Saputri, 2016), (Jufrizen \& Asfa, 2015), (Warouw et al., 2016) which states that profitability has no effect on the company's financial performance.

\section{Conclusions}

Based on statistical calculations that have been carried out on this research, it can be concluded that:(1) Environmental performance has no impact on the financial performance of Pharmaceutical companies listed on the Stock Exchange for the 2017-2019 period. The absence of environmental performance on financial performance does not mean that the company does not care about the surrounding environment, but it could be that the company has paid attention to the environment in which the company operates, because by paying attention to the environment due to the company's operations, it is a form of company concern for the consequences of its operations. a company that is certain to have an impact;(2) Intellectual variables as proxied by VAIC also have not been able to improve the company's financial performance. This lack of intellectual capital could be because the company has not been optimal in increasing its intellectual resources because it is still focused on the company's short-term goals; (3) The variable of corporate social responsibility disclosure has a positive influence on the company's financial performance. The influence of corporate social responsibility on financial performance indicates that the company has implemented a level of concern for the existence of the community by taking part in community welfare programs around the company ;(4) Environmental performance has no significant effect on financial performance. The absence of environmental performance on financial performance does not mean that the company does not care about the surrounding environment, but that the company's efforts towards the surrounding environment can be said to have not been maximized; (5) Intellectual capital has no significant effect on financial performance. Intellectual capital has no effect on financial performance because the company's attention has not been maximized on knowledge assets rather than human resources owned by the company; (6) Corporate social responsibility has a negative and significant effect on financial performance. The influence of corporate social responsibility on financial performance indicates that the company's efforts to care for the social environment of the community have been maximized so that it can have an impact on the company's financial performance; (7) The company's profitability has a negative and significant effect on financial performance. These findings indicate that profitability can improve the company's financial performance.

\section{Suggestion}

Referring to the results of the discussion and conclusions, some suggestions can be put forward as follows: (1) For companies should improve environmental performance, intellectual capital, as well as corporate social responsibility, because it is considered an important aspect in increasing the profitability and financial performance of the company. Environmental performance, and corporate social responsibility will be important indicators related to the company's reputation and compliance with corporate ethics, which can provide benefits to the company. While intellectual capital if managed optimally will create a competitive advantage for the company.; (2) For further research, other variables should be used, such as from good corporate governance, capital structure, and others, so that the findings are better in explaining profitability and financial performance. In addition, it is also necessary to consider using other company sectors such as banking, manufacturing, and others, so that they are more representative of company behavior on the Indonesia Stock Exchange. 


\section{References}

[1] Agustina, W., Yuniarta, G. A., \& Sinarwati, N. K. (2015). Pengaruh Intellectual Capital, Corporate Governance dan Corporate Social Responsibility Terhadap Kinerja Keuangan. e-Journal Akuntansi Universitas Pendidikan Ganesha, 3(1), 1-11. https://ejournal.undiksha.ac.id/index.php/S1ak/article/view/4726/35 93

[2] Al-Tuwaijri, S. A., Christensen, T. E., \& Hughes, K. . (2004). The relations among environmental disclosure, environmental performance, and economic performance: a simultaneous equations approach. Accounting, Organizations and Society, 29(56), 447-471. doi:10.1016/s0361-3682(03)00032-1

[3] Angelia, D., \& Suryaningsih, R. (2015). The Effect of Environmental Performance And Corporate Social Responsibility Disclosure Towards Financial Performance (Case Study to Manufacture, Infrastructure, And Service Companies That Listed At Indonesia Stock Exchange). Procedia - Social and Behavioral Sciences, 211, 348-355. doi:10.1016/j.sbspro.2015.11.045

[4] Aniela, Y. (2012). Peran Akuntansi Lingkungan Dalam Meningkatkan Kinerja Lingkungan Dan Kinerja Keuangan Perusahaan. Berkala Ilmiah Mahasiswa Akuntansi, 1(1), 15-19. http://journal.wima.ac.id/index.php/BIMA/article/view/24

[5] Asjuwita, M., \& Agustin, H. (2020). Engaruh Kinerja Lingkungan Dan Biaya Lingkungan Terhadap Profitabilitas Pada Perusahaan Manufaktur Yang Terdaftar Di Bursa Efek Indonesia Tahun 2014 2018. JURNAL EKSPLORASI AKUNTANSI, 2(3), 3327-3345. doi:10.24036/jea.v2i3.285

[6] Astuti, F. P., Aniskurlillah, I., \& Murtini, H. (2014). Pengaruh Kinerja Lingkungan Dan Kepemilikan Asing Terhadap Kinerja Keuangan. Accounting Analysis Journal, 3(4), 493-500. doi: 10.15294/aaj.v3i4.4211

[7] Azzahra, K. (2020). THE INFLUENCE OF INTELLECTUAL CAPITAL AND SHARIA COMPLIANCE TO THE BANKING FINANCIAL PERFORMANCE IN INDONESIA. JARES (Journal of Academic Research and Sciences), 5(1), 14-26. doi:10.35457/jares.v5i1.900

[8] Bidhari, S. C., Salim, U., Aisjah, S., \& Java, E. (2013). Effect of Corporate Social Responsibility Information Disclosure on Financia Performance and Firm Value in Banking Industry Listed at Indonesia Stock Exchange. European Journal of Business and Management, 5(18), 39-47.

[9] Intan Cahyani, R., Widiarti S, T., \& Listya Ferdiana, J. (2015). Pengaruh Intellectual Capital terhadap Profitabilitas pada Perusahaan Manufaktur yang Terdaftar di Bursa Efek Indonesia. Jurnal Riset Akuntansi \& Perpajakan (JRAP), 2(01), 1-18. doi:10.35838/jrap.v2i01.88

[10] Cahyaningrum, A. D., \& Atahau, A. D. R. (2021). INTELLECTUAL CAPITAL AND FINANCIAL PERFORMANCE: BANKS' RISK AS THE MEDIATING VARIABLE. Jurnal Manajemen Dan Kewirausahaan, 22(1), 21-32. doi:10.9744/jmk.22.1.21-32

[11] Cahyono, D. \& Qomariah, N. (2017). INTELECTUAL CAPITAL DAN KINERJA PERUSAHAAN. Cahaya IImu. https://www.researchgate.net/publication/326622457_INTELECTU AL CAPITAL DAN KINERJA PERUSAHAAN

[12] Cho, S. J., Chung, C. Y., \& Young, J. (2019). Study on the relationship between CSR and financial performance. Sustainability (Switzerland), 11(2), 1-26. doi: 10.3390/su11020343

[13] Darmawati, D. (2015). Pengaruh Tanggung Jawab Sosial Perusahaan Terhadap Kinerja Dan Risiko Perbankan Di Indonesia. Finance and Banking Journal, 17(1), 83-97.

[14] Deswanto, R. B., \& Siregar, S. V. (2018). The associations between environmental disclosures with financial performance, environmental performance, and firm value. Social Responsibility Journal, 14(1), 180-193. doi:10.1108/sri-01-2017-000

[15] Dženopoljac, V., Janoševic, S., \& Bontis, N. (2016). Intellectual capital and financial performance in the Serbian ICT industry. Journal of Intellectual Capital, 17(2), 373-396. doi:10.1108/jic-072015-0068

[16] Elsayed, K., \& Paton, D. (2005). The impact of environmental performance on firm performance: static and dynamic panel data evidence. Structural Change and Economic Dynamics, 16(3), 395412. doi:10.1016/j.strueco.2004.04.004

[17] Fitriani, A. (2013). Pengaruh Kinerja Lingkungan dan Biaya Lingkungan terhadap Kinerja Keuangan pada BUMN. Jurnal IImu Manajemen (JIM), 1(1), 137-148.
[18] Gama, A. W. S., Wiagustini, N. L. P., Sedana, I. B. P., \& Purbawangsa, I. B. A. (2020). Intellectual capital and financial performance of Indonesian banks. Quality - Access to Success, 21(177), 9-14.

[19] Gantino, R. (2016). Pengaruh Corporate Social Responsibility Terhadap Kinerja Keuangan Perusahaan Manufaktur yang Terdaftar di Bursa Efek Indonesia periode 2008-2014. Jurnal Dinamika Akuntansi Dan Bisnis, 3(2), 19-32. doi:10.24815/jdab.v3i2.5384

[20] Gozali, A., \& Hatane, S. E. (2014). Pengaruh Intellectual Capital Terhadap Kinerja Keuangan Dan Nilai Perusahaan Khususnya Di Industri Keuangan Dan Industri Pertambangan Yang Terdaftar Di Bursa Efek Indonesia Tahun 2008 - 2012. Business Accounting Review, 2(2),

208-217. http://publication.petra.ac.id/index.php/akuntansibisnis/article/view/2401

[21] Gumanti, tatang A. (2011). Manajemen Investasi, Konsep, teori dan Aplikasi. Mitra Wacana Media.

[22] Habibah, B. N., \& Riharjo, I. B. (2016). Pengaruh Intellectual Terhadap Kinerja Keuangan Pada Perusahaan Manufaktur. Jurnal IImu Dan Riset Akuntansi, 5(Ic), 1-16.

[23] Hadi, N. (2011). Corporate Social Responsibility. Graha IImu.

[24] Hafidzi, A. H., \& Qomariah, N. (2020). IMPACT OF CORPORATE SOCIAL RESPONSIBILITY ON STOCK PRICES THROUGH FINANCIAL PERFORMANCE IN MANUFACTURING COMPANIES LISTED ON THE IDX IN THE COVID ERA 19. International Journal of Advanced Research in Engineering and Technology (IJARET), 11(11), 1510-1520. doi: 10.34218/IJARET.11.11.2020.139

[25] Haholongan, R. (2016). Kinerja Lingkungan dan Kinerja Ekonomi Perusahaan Manufaktur Go Public. Jurnal Ekonomi Dan Bisnis, 19(3), 413. doi:10.24914/jeb.v19i3.477

[26] Halim, A., Basri, H., \& Faisal. (2016). Pengaruh Itellectual Capital Terhadap Profitabilitas Dan Dampaknya Terhadap Harga Saham Perusahaan Sektor Keuangan Yang Terdaftar Di Bursa Efek Indonesia (BEI). Jurnal Bisnis dan Ekonomi (JBE), 23(2), 124-141.

[27] Hamdani, M. (2014). Hubungan Pengungkapan Corporate Social Responsibility (CSR) Terhadap Kinerja Keuangan dan Harga Saham Pada Perusahaan LQ45. Jurnal Organisasi dan Manajemen, 10, 27-36. http://jurnal.ut.ac.id/index.php/jom/article/view/112/97

[28] Hardiyansah, M., \& Agustini, A. T. (2020). Analysis of carbon emissions disclosure and firm value: Type of industry as a moderating model. International Journal of Scientific and Technology Research, 9(2), 1125-1132.

[29] Haryanto, M., \& Henny. (2013). Pengaruh Intellectual Capital Terhadap Kinerja Keuangan Dan Nilai Pasar Perusahaan. Jurnal Manajemen Maranatha, 12(2), 133-148. https://journal.maranatha.edu/index.php/jmm/article/view/161

[30] Hermanus, I. G., Evelyn, \& Patricia, L. W. (2013). Pengaruh Intellectual Capital terhadap Profitabilitas, Produktivitas, dan Penilaian Pasar Perusahaan Sektor Perbankan. Jurnal GEMA AKTUALITA, 2(2), 29-40.

10.1016/j.atherosclerosis.2012.11.023

[31] Hidayah, N. A., Nurcholisah, K., Fitriah, E., \& Faculty, B. (2020). The Effects of Intellectual Capital and Institutional Ownerships on the Financial Performance (Empirical Study on the Listed of Banking Companies, the Indonesia Stock Exchange Periods of 2015-2017. Research Journal of Finance and Accounting, 11(10), 82-85. doi: 10.7176/rifa/11-10-09

[32] https://industri.kontan.co.id/news/sektor-industri-menyumbang-19pdb-indonesia-di-kuartal-pertama-2020.

[33] Https://republika.co.id/berita/qdgt5p383/tiga-dampak-besarpandemi-covid19-bagi-ekonomi-ri.

[34] Ihyaul, U. (2009). Intellectual Capital: Konsep dan Kajian Empiris. Graha IImu.

[35] Iskandar, R., Azis, M., \& Rahmat, N. (2019). Vaic mediated by financial performance and gcg increase stock prices. International Journal of Scientific and Technology Research, 8(12), 164-168.

[36] Janosevic, S., \& Dzenopoljac, V. (2011). Intellectual capital and financial performance of Serbian companies in the real sector. Ekonomika Preduzeca, 59(7-8), 352-366. doi:10.5937/ekopre1108352j

[37] Jordão, R. V. D., \& Almeida, V. R. de. (2017). Performance measurement, intellectual capital and financial sustainability. Journal of Intellectual Capital, 18(3), 643-666. doi:10.1108/jic-112016-0115 
[38] Khasanah, A. N. (2016). Pengaruh Intelektual Capital dan Islamicity Performance Index Terhadap Kinerja Keuangan Perbankan Syariah di Indonesia. Jurnal Nominal, V(6), 1-18. https://journal.uny.ac.id/index.php/nominal/article/view/11473/8328

[39] Kurniawan, I. S. (2013). Ntellectual Capital Terhadap Kinerja Keuangan Perusahaan Publik Di Indonesia. Jurnal Keuangan dan Perbankan, 17(1), 21-35.

[40] Kusuma, D., \& Syafruddin, M. (2014). Analisis Pengaruh Corporate Social Responsibility Terhadap Kinerja Keuangan Perusahaan Dengan Manajemen Laba Sebagai Variabel Pemoderasi. DIPONEGORO JOURNAL OF ACCOUNTING, 3(1), 52-64. https://ejournal3.undip.ac.id/index.php/accounting/article/view/601 $9 / 5807$

[41] Lestari, H. S. (2017). PENGARUH INTELLECTUAL CAPITAL TERHADAP KINERJA PERUSAHAAN ASURANSI DI INDONESIA Jurnal Manajemen, 21(3), 491. doi:10.24912/jm.v21i3.264

[42] Dwie Lestari, S., Paramu, H., \& Sukarno, H. (2017). PENGARUH INTELLECTUAL CAPITAL TERHADAP KINERJA KEUANGAN PERBANKAN SYARI'AH DI INDONESIA. EKUITAS (Jurna Ekonomi Dan Keuangan), 20(3), 346 doi:10.24034/j25485024.y2016.v20.i3.1838

[43] Manrique, S., \& Martí-Ballester, C.-P. (2017). Analyzing the Effect of Corporate Environmental Performance on Corporate Financia Performance in Developed and Developing Countries. Sustainability, 9(11), 1957. doi:10.3390/su9111957

[44] Mardiana, I. A., \& Wuryani, E. (2019). AKUNESA : Jurnal Akuntansi Unesa PENGARUH KINERJA LINGKUNGAN TERHADAP NILAI PERUSAHAAN AKUNESA: Jurnal Akuntansi Unesa Akunesa:Jurnal Akuntansi Unesa, 8(1). http://riset.unisma.ac.id/index.php/jra/article/view/6138

[45] Marfuah, \& Ulfa, M. (2014). Pengaruh Intellectual Capital Terhadap Profitabilitas, Produktivitas dan Pertumbuhan Perusahaan Perbankan Marfuah. Jurnal Ekonomi dan Bisnis Islam, IX(1), 1-14.

[46] Meiyana, A., \& Aisyah, M. N. (2019). PENGARUH KINERJA LINGKUNGAN, BIAYA LINGKUNGAN, DAN UKURAN PERUSAHAAN TERHADAP KINERJA KEUANGAN DENGAN CORPORATE SOCIAL RESPONSIBILITY SEBAGAI VARIABEL INTERVENING. Nominal: Barometer Riset Akuntansi Dan Manajemen, 8(1), 1-18. doi:10.21831/nominal.v8i1.24495

[47] Muhammad, N., Scrimgeour, F., Reddy, K., \& Abidin, S. (2015). The relationship between environmental performance and financial performance in periods of growth and contraction: evidence from Australian publicly listed companies. Journal of Cleaner Production, 102, 324-332. doi:10.1016/j.jclepro.2015.04.039

[48] Muhammad, R., Mangawing, M. A., \& Salsabilla, S. (2021). The influence of intellectual capital and corporate governance on financial performance of Islamic banks. Jurnal Ekonomi \& Keuangan Islam, 7(1), 77-91. doi:10.20885/jeki.vol7.iss1.art6

[49] Nakao, Y., Amano, A., Matsumura, K., Genba, K., \& Nakano, M. (2007). Relationship between environmental performance and financial performance: an empirical analysis of japanese corporations. Business Strategy and the Environment, 16(2), 106118. doi:10.1002/bse.476

[50] Nawangsari, R. D., \& Ika Nugroho, P. (2019). Pengaruh Indikato Kinerja Ekonomi, Indikator Kinerja Lingkungan dan Indikator Kinerja Sosial terhadap Profitabilitas Perusahaan Manufaktur. International Journal of Social Science and Business, 3(2), 162 doi:10.23887/ijssb.v3i2.17644

[51] Nurhayati, S. (2017). ANALISA PENGARUH INTELLECTUAL CAPITAL TERHADAP KINERJA PASAR DAN KINERJA KEUANGAN PADA PERUSAHAAN LQ45 YANG TERDAFTAR DI BURSA EFEK INDONESIA PERIODE TAHUN 2010-2013. Jurnal ASET (Akuntansi Riset), 9(1), 133. doi:10.17509/jaset.v9i1.5260

[52] Nurhudha, A. S., \& Suwarti, T. (2013). Analisis Pengaruh Corporate Social Responsisbility, Intellectual Capital, dan Kinerja Lingkungan Terhadap Kinerja Keuangan Perusahaan Manufaktur yang Terdaftar di Bursa Efek Indonesia. Prosiding Seminar nasional Mult Disiplin IImu \& Call For Papers UNISBANK, 53(9), 1689-1699.

[53] Nursaid, N., Qomariah, N., \& Satoto, E. B. (2020). Efforts to Improve the Financial Performance of Manufacturing Companies Based on Environmental Performance, Corporate Social Responsibility and Intellectual Capital. International Journal of Engineering Research and Technology., 13(11), 3278-3286

[54] Ong, T. S., Lee, A. S., Teh, B. H., \& Magsi, H. B. (2019). Environmental innovation, environmental performance and financia performance: Evidence from Malaysian environmental proactive firms. Sustainability (Switzerland), 11(12), 1-18. doi: 10.3390/su10023494

[55] Ongkorahardjo, M. D. P., Susanto, A., \& Rachmawati, D. (2008). Analisis Pengaruh Human Capital Terhadap Kinerja Perusahaan (Studi Empiris pada Kantor Akuntan Publik di Indonesia). Jurnal Akuntansi dan Keuangan, 10(1), 11-21. doi: 10.9744/jak.10.1.PP.11-21

[56] Parengkuan, W. (2017). Pengaruh Corporate Social Responsibility(Csr) Terhadap Kinerja Keuangan Perusahaan Manufaktur Yang Terdaftar Di Bursa Efek Indonesia Melalui Pojok Bursa Feb Â€“ Unsrat. Jurnal Riset Ekonomi, Manajemen, Bisnis dan Akuntansi, 5(2), 564-571. doi: 10.35794/emba.v5i2.15726

[57] Patten, D. M. (1992). Intra-industry environmental disclosures in response to the Alaskan oil spill: A note on legitimacy theory. Accounting, Organizations and Society, 17(5), 471-475. doi:10.1016/0361-3682(92)90042-q

[58] Pramukti, A., \& Buana, A. P. (2019). Pengungkapan Tanggungjawab Sosial dan Kinerja Keuangan. Owner, 3(2), 301. doi:10.33395/owner.v3i2.153

[59] Putra, A. S. (2016). PENGARUH CORPORATE SOCIAL RESPONSIBILITY TERHADAP PROFITABILITAS PERUSAHAAN (Studi Empiris pada Perusahaan Sektor Industri Barang Konsumsi yang Terdaftar di Bursa Efek Indonesia Tahun 2010-2013). Nominal, Barometer Riset Akuntansi Dan Manajemen, 4(2). 16-22, doi:10.21831/nominal.v4i2.8002

[60] Putra, Y. P. (2018). Pengaruh Kinerja Lingkungan Terhadap Kinerja Keuangan Dengan Pengungkapan Corporate Social Responsibility (CSR) Sebagai Variabel Intervening. BALANCE Jurnal Akuntansi Dan Bisnis, 2(2), 227. doi:10.32502/jab.v2i2.1175

[61] Putri, A. M., Hidayati, N., \& Amin, M. (2019). Dampak Penerapan Green Accounting dan Kinerja Lingkungan Terhadap Profitabilitas Perusahaan Manufaktur Di Bursa Efek Indonesia. E-JRA Fakultas Ekonomi dan Bisnis Universitas Islam Malang, 08(04), 149-164.

[62] Qomariah, N. (2015). The Effect of Corporate Social Responsibility, Size, and Profitability Toward On the Value of Corporate. Journal of Business and Management, 17(2), 25-30. doi: 10.9790/487X17212530

[63] Qomariah, N., Martini, N., \& Paramu, H. (2019). Strategy For Increasing Profitability Based On Corporate Governance Corporate Social Responsibility And Intellectual Capital ( Study On Halal Certified Food Industries Registered On The Indonesia Stock Exchange For The 2013-2016 Period ). 9(6), 56-61.doi: 10.9790/5933-0906025661

[64] Rahayu, W., Darminto, \& Topowijoyo. (2014). PENGARUH PENGUNGKAPAN CORPORATE SOCIAL RESPONSIBILITY (CSR) TERHADAP PROFITABILITAS PERUSAHAAN (Studi Pada Perusahaan Sektor Pertambangan Periode 2012-2013 yang Terdaftar di Bursa Efek Indonesia). Jurnal Administrasi Bisnis S1 Universitas Brawijaya, 17(2)

[65] Santoso, S. (2011). Pengaruh Modal Intelektual dan Pengungkapannya Terhadap Kinerja Perusahaan. Jurnal Akuntansi Dan Keuangan, 14(1). doi:10.9744/jak.14.1.16-31

[66] Sari, eka N., \& Sinambela, E. (2008). Pengaruh Pengungkapan Tanggung Jawab Sosial Perusahaan Terhadap Kinerja Keuangan Perusahaan (Studi Empiris pada Perusahaan Perkebunan di Sumatera Utara) Eka. Jurnal Riset Akuntansi dan Bisnis, 8(2), 121. http://jurnal.umsu.ac.id/index.php/akuntan/article/view/447/pdf_75

[67] Setyaningsih, R. D., \& Asyik, N. F. (2016). Pengaruh Kinerja Lingkungan Terhadap Kinerja Keuangan Dengan Corporate Social Responsibility sebagai Pemoderasi. Jurnal IImu dan Riset Akuntansi, 5(4), 1-15.

[68] Silviani, D. A., \& Noekent, V. (2020). An Indonesian Empirical Study of The Relationship between Firm's Intellectual Capital, Financial Performance and Market Value. Management Analysis Journal, 9(4), 451-458. doi:10.15294/maj.v9i4.40844

[69] Sirojudin, Gatot Ahmad; Nazaruddin, I. (2014). Pengaruh Modal Intelektual dan Pengungkapannya Terhadap Nilai dan Kinerja Perusahaan. Jurnal Akuntansi dan Keuangan, 15(2), 77-89. doi: 10.18196/JAI-2015.0035

[70] Suciwati, D. P., Pradnyan, D. P. A., \& Ardina, C. (2016). PENGARUH CORPORATE SOCIAL RESPONSIBILITY TERHADAP KINERJA KEUANGAN (Pada Perusahaan Sektor Pertambangan di BEI Tahun 2010-2013). Jurnal Bisnis Dan Kewirausahaan, 12(2), 104-113.

[71] Sudaryanti, D., \& Riana, Y. (2017). PENGARUH 


\section{GENERAL MANAGEMENT}

PENGUNGKAPAN CSR TERHADAP KINERJA KEUANGAN PERUSAHAAN. Jurnal Penelitian Teori \& Terapan Akuntansi (PETA), 2(1), 19-31. doi:10.51289/peta.v2i1.273

[72] Sumani, \& Suryaningsih, I. B. (2020). Intellectual capital, capita structure and growth of the company and its implications on value index formers Lq-45. International Journal of Scientific and Technology Research, 9(1), 4182-4189.

[73] Suseno, N. S., Hermina, T., Ramdhani, A., \& Utari, L. (2019). The impact of intellectual capital on financial performance. International Journal of Recent Technology and Engineering, 8(1), 359-365. doi: 10.30871/jama.v1i1.1239

[74] Tahu, G. P. (2019). Pengaruh KInerja LIngkungan Dan Pengungkapan Lingkungan Terhadap KInerja Keuangan (Stud Pada Perusahaan Manufaktur yang Terdaftar di BEI). Jurnal Akuntansi, Audit dan Sistem Informasi Akuntansi, 3(1), 14-26.

[75] Tang, Z., Hull, C. E., \& Rothenberg, S. (2012). How Corporate Social Responsibility Engagement Strategy Moderates the CSRFinancial Performance Relationship. Journal of Management Studies, 49(7), 1274-1303. doi:10.1111/j.1467-6486.2012.01068.x

[76] Testa, F., Iraldo, F., \& Frey, M. (2011). The effect of environmental regulation on firms' competitive performance: The case of the building \& construction sector in some EU regions. Journal of Environmental Management, 92(9), 2136-2144. doi 10.1016/j.jenvman.2011.03.039
[77] Untung, B. H. (2009). Corporate Social Responsibility. Sinar Grafika.

[78] W, I. F. S., \& Firmansyah, R. (2012). Pengaruh Intellectual Capital Terhadap Kinerja Keuangan Perusahaan (Studi Empiris Perusahaan Lq 45). Jurnal Dinamika Akuntansi, 4(1), 1-12. doi: 10.15294/jda.v4i1.1954

[79] Yoon, B., \& Chung, Y. (2018). The effects of corporate social responsibility on firm performance: A stakeholder approach. Journal of Hospitality and Tourism Management, 37, 89-96. doi:10.1016/j.jhtm.2018.10.005

[80] Yulianingtyas, D. (2016). Pengaruh Corporate Social Responsibility Dan GoodCorporate Governance Terhadap Kinerja Perusahaan. Jurnal IImu dan Riset Manajemen, 5(1994), 1-21.

[81] Yurianda, D., \& Masdupi, E. (2020). The Effect of Capital Structure and Intellectual Capital on Corporate Value with Financial Performance as Intervening Variable. Proceedings of the 4th Padang International Conference on Education, Economics, Business and Accounting (PICEEBA-2 2019). doi:10.2991/aebmr.k.200305.162

[82] Yusuf, A. U., Rasyid, S., \& Rura, Y. (2020). The Effect of Intellectual Capital and Supply Chain Management on the Financial Performance by Using Cost Leadership Strategy as Moderating Variable. International Journal of Innovative Science and Research Technology, 5(2), 290-300. www.ijisrt.com290 